
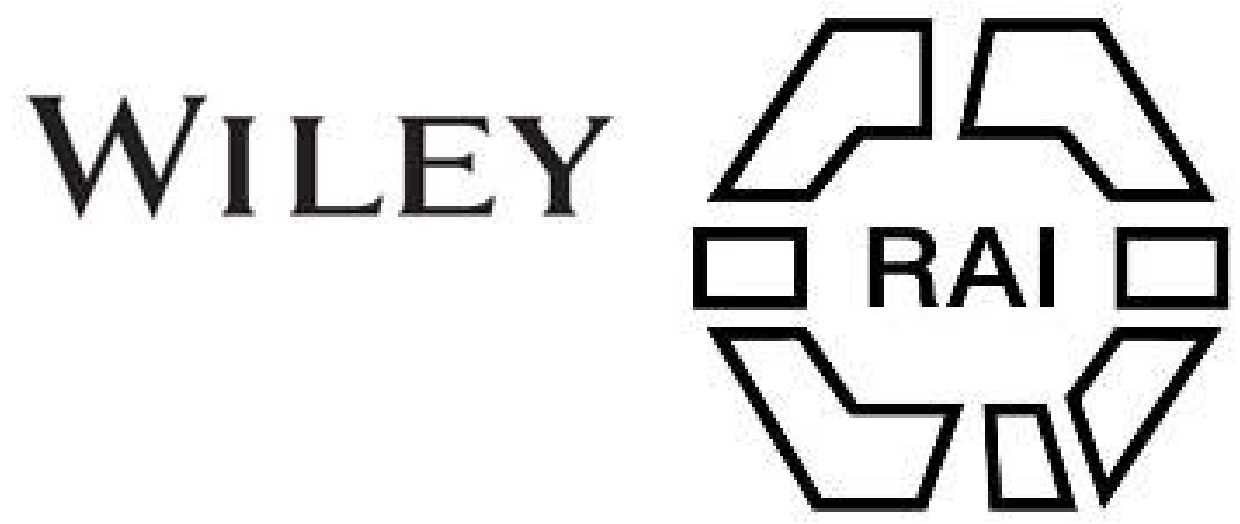

100. (II) Metal Work

Author(s): N. W. Thomas

Source: Man, Vol. 18 (Dec., 1918), pp. 184-186

Published by: Royal Anthropological Institute of Great Britain and Ireland

Stable URL: http://www.jstor.org/stable/2788512

Accessed: 27-06-2016 07:38 UTC

Your use of the JSTOR archive indicates your acceptance of the Terms \& Conditions of Use, available at

http://about.jstor.org/terms

JSTOR is a not-for-profit service that helps scholars, researchers, and students discover, use, and build upon a wide range of content in a trusted digital archive. We use information technology and tools to increase productivity and facilitate new forms of scholarship. For more information about JSTOR, please contact support@jstor.org.

Wiley, Royal Anthropological Institute of Great Britain and Ireland are collaborating with JSTOR to digitize, preserve and extend access to Man 


\section{Nigerian Notes.}

(II) Metal Work. By N. W. Thomas.

the only two which are of real industrial importauce among the. Edo are iron and brass ; the use of the former of these two is again not unnaturally far more extensive than that of the other, and it is rare to find a village of any size without one or even two smithies, which serve as a meeting place in the hot hours of the early afternoon. Work in the smithy is carried on at irregular intervals, and the blacksmith is seldom or never wholly dependent on his craft for a living.

The case of the brass workers is somewhat different; they are, comparatively speaking, an organised body in Edo, with a chief at their head; they live in one street for the most part, and if they now turn to other work to eke out a livelihood it seems likely that it is a late development due to the alteration of conditions.

(a) Iron.

In the case of a blacksmith in the village the craft may well be hereditary, though I never found a son at work with his father. In Edo a boy is sent to learn the work at an early age-seven or soon after; a fee is paid by the father - said to be 5l.- and a sacrifice is offered to Ogun, the deity of blacksmiths.

The tools of blacksmiths and brass-smiths are to some extent identical, but for the latter the file is more useful than the hammer. The blacksmith makes his own tools : a hammer (umomo), sometimes conical, sometimes square; a firehook (ukwere), an anvil, consisting of a stout iron pin with a circular top; a file and a chisel. The bellows ( $\underline{e} k w \underline{e})$ are of goatskin, two bags with wooden handles tied in the centre, the air being expelled through two conical pottery tubes (obwe) fixed in the block of wood, on the top of which are the aperture for the skins. The bellows are fixed in the ground, and the nozzles are hidden in the ashes. Sometimes a boy acts as blower, sometimes the bringer of an article to be repaired undertakes the job.

The main work to be done is the repair of matchets for field work, of hoes, and of minor articles such as chains, toy bows and arrows, and other objects used in the cults. Some of these latter are usually to be found in the market. Tools are also made for leather workers, carpenters, and others; and hand or stand lamps (orukpa) may be made when there is a purchaser. These lamps are flat bowls, the stand lamps with a long stem for planting in the ground, the hand lamps with a double bow and chuin over the howl; in each case there is a spoon for the oil and a "tortoise" to be placed on the cotton wick to prevent the flame from spreading too far.

Other articles of manufacture are hinges (olodu), door keys (isahe), women's hairpins and knives, men's knives, and Osun, an account of which is given in another section.

For the working of iron the azemomo tree is cut while it is green, and the logs piled up without being dried and fired at once; the charcoal (enii) is b ought home. To light the tire a brand is taken from the house and carried to the smithy with the aid of pincers.

In parts of Northern Nigeria, such as Uyame, in the north-east of the Central Province, iron is also smelted from ore. I witnessed the operation only once-at Megeri-and ignorance of the language prevented me from ascertaining details. The conical furnace was of clay beneath a hut, about 4 feet high, with a hole sunk in the centre. So far as I could ascertain, ore and wood are put in alternate layers, and the bellows worked until the metal flows into the hole beneath the cone. 'The pigs are probably small; iron is chipped off them for use with a hammer or chisel. 
The bellows consisted of a piece of skin, three or four feet square, which was simply pulled in and out by a man.

\section{(b) Brass.}

The brass workers say that they are descended from the Kings of Ufe, one of whom married the daughter of a brass worker. She bore seven sons, and all but the youngest became kings; the youngest son reflected that his mother was the daughter of a brass worker and became himself a blacksmith. From Ufe he was sent to Edo to greet the king, and remained there to found the colony of brass workers.

A boy is apprenticed at an early age; or, if he comes from the family of the chief, he comes as a learner and receives a wife when he is marriageable.

At an early age a boy learns to make moulds for the small hawk bells that are worn by children, and occasionally figure on the ceremonial dress of a priest. A clay or mud core is prepared by one boy; another takes bees-wax, probably mixed with oil to soften it, and rolls it out in long strings with a cam-wood roller and board; when the string is finished it is laid in some cross wires; then the other boy takes it and winds it round the clay core in the pattern to be produced, with a final curl to represent the handle. When a sufficient number of these moulds are prepared, they are set in a large pot, arranged as it were like grapes on a bunch, the stalks being the lines along which the molten metal is to run. This mould ready, it is heated in the fire and the wax run out; it is then ready for the casting.

At present brass seems to be obtained from European sources; formerly it was got from the king, and was naturally of a different quality. It is broken up and put in a clay or sand crucible over the fire, or, rather, imbedded in the fire, which is blown up with the bellows. When the brass is in a liquid state it is poured into the mould, which is then immersed in water and broken to extract the bells; the excrescences are filed off, and after being rubbed with sand the bells are ready for salc.

At the present day there is not a large sale for genuine native work of the old type. A certain number of bracelets are, no doubt, made; occasionally a brass-hilted knife may be manufactured; and an uhumexwe, or face-mask, formerly worn by chiefs on the left side when they went to visit the king, can still be turned out in creditable style.

The majority, however, of the modern articles are of inferior metal, badly modelled, and altogether different from the old style. They are made for sale to Europeans, and depict recent events or scenes of every-day life; occasionally armlets are turned out for the same purpose. In old days, however, many more articles were required ; dishes. (of wood) for the king's use were ornamented with brass; bells, lamps, and ceremonial objects of all sorts must have been needed; and possibly a certain amonnt may have been exported.

Objects figured in Antiquities from Benin City are seldom recognised by modern brass-smiths as in any way resembling the work which they put out; uhumexwe, asan, and a few other objects complete the list. The old brass ware does not seem to have wandered far from Edo; but occasionally $I$ found in other parts of the country objects which from their style of workmanship might have been produced in Edo. Such, for example, was a leopard's head sold to me at Okpe.

There are but few old bronzes obtainable at the present day. I procured a fragment of a necklace, said to have been worn by Osuon, and a figurine, $23 \mathrm{~cm}$. high, of a woman with Usen marks, holding what may be intended to represent a tension drum in her two hands. I also saw in Edo a broken lamp pedestal of bronze, hollow, with an earthy core; on the disks which stund out from the central staff are decorative heads. 
Brass hair pins with broad ends decorated with incised lines or punched holes are common in the Ora country; they seem to be made by blacksmiths.

Beyond the making of the bells I had no opportunity of seeing castings made in Edo; but $I$ saw a brass-smith at work with his hammer occasionally. He used a hammer in shape something like a tent peg but the flat edge was used to strike the object with. In one case a piece of brass with a hook at each end was straightened and then made four square with rapid blows on each side, the bar being turned $90^{\circ}$ each time. I was struck with the accuracy of the work.

N. W. THOMAS.

\section{Geology.}

Greenhithe Shell-bed. By Reginald A. Smith, F.S.A.

An examination of the Stopes collection, in course of arrangement for the II National Museum of Wales, has revealed some additional evidence as to the date of the shell-bed at Ingress Vale, Greenhithe, Kent, the material from which is now scattered in several collections. Unfortunately, the comparatively large series now at Cardiff is not accompanied by any stratigraphical record, but the site was evidently occupied as late as Le Moustier times, though the fauna of the main deposit has been referred to the Pliocene (witness the Trogontherium and Neritina grateloupiana). The excavation undertaken in 1913 on behalf of the British Museum and the Geological Survey (see Archceologia, LXV, 192) yielded no less than 500 flakes, but no implements of any kind, which was disappointing, in view of the many fine specimens of St. Acheul type obtained previously by several collectors.

The critical point was, and is, the relation of these ovates to the seam of Pliocene shells, and it will perhaps never be decided, as very little remains of the deposit; but the late Mr. Stopes collected enough to establish a sequence, even though the occurrence of several types on the same site may revive the contention that all types occur together at all periods.

Apart from broken material and mere flakes (some of which closely resemble the series in the British Museum), the following were the principal items :-

5 specimens chipped in eolithic style, one apparently a true eolith.

2 rolled hand-axes, one triangular and ochreous, the other with squared point and notch below it.

1 rolled ochreous hand-axe, triangular, with cutting-edge below, and a paler specimen with reversed S-twist on one side.

1 heavy hand-axe, mottled brown and yellow, much rolled, scratched, and glossy.

11 broken implements of various types, two of them rolled.

2 twisted implements, both with reversed S-curve.

19 small, unrolled, pear-shaped hand-axes of the type commonly found in the Barnfield pit opposite.

37 other implements of various ordinary types, six with white or creamy patina.

15 ovates, most with basil point (en biseau), including one deeply ochreous, but little rolled.

4 cordates, one regular and another heavily rolled.

1 cordate implement with one face flaked quite flat, the other apparently unfinished.

9 good round-headed and 16 square-headed scrapers, mostly made from mediumsized flakes.

14 flakes used as hollow-scrapers.

22 square-nosed flakes, most with terminal, and a. few with lateral, nose and 7 special cases with nose curved to the left and a notch below it.

3] flakes of all shapes, with "spurs" of different widths at end or side. 